\title{
Glutathione Synthetase Deficiency
}

National Cancer Institute

\section{Source}

National Cancer Institute. Glutathione Synthetase Deficiency. NCI Thesaurus. Code C128193.

An autosomal recessive genetic disorder caused by mutation(s) in the GSS gene, encoding glutathione synthetase. Mutation(s) in the same gene is causative in hemolytic anemia due to glutathione synthetase deficiency, with the more severe condition causing elevated urinary concentrations of 5-oxoproline and central nervous system damage in addition to hemolytic anemia. 